\title{
The Urgency of Strengthening Appraisal Regulations to Realize a Legal Protection for Appraiser
}

\author{
Lastuti Abubakar, Tri Handayani \\ Faculty of Law, Padjadjaran University, Bandung, Indonesia. E-mail: lastuti62abubakar@gmail.com \\ Faculty of Law, Padjadjaran University, Bandung, Indonesia. E-mail: tri.handayani@unpad.ac.id
}

\begin{tabular}{l} 
ARTICLE INFO \\
\hline Keywords: \\
appraiser; appraisal of \\
banking; collateral; loan \\
and financing; \\
responsibility. \\
How to cite: \\
Abubakar L. E Handayani \\
T.(2019). The Urgency of \\
Strengthening Appraisal \\
Regulations to Realize a \\
Legal Protection for \\
Appraiser. \\
MEDIA HUKUM, +62 \\
274 387656 (Ext. 220 ) \\
Article History: \\
Received: 02-08-2019 \\
Reviewed: 17-09-2019 \\
Revised: 07-10-2019 \\
Accepted: 23-12-2019
\end{tabular}

\begin{abstract}
To provide legal protection and legal certainty for service users and Appraisers, the Government, in this case, the Ministry of Finance requires the Public Appraisal profession to obtain a permit in supporting financial service sector. The research describes the position and responsibility of Appraisers in assessing collateral for loan and finance, that in practice, often requires Appraisers' administrative, civil, and criminal responsibilities. The article uses a multi-interdisciplinary approach by applying status, comparative, and case study. The results show that a key for legal protection for appraiser comes from a legal relationship between an Appraiser and a Bank. The assessment of collateral for bank loan and financing, arises from collateral appraisal cooperation agreements; and from the legal provisions, including Regulation of the Ministry of Finance on Public Appraisal and the other related Laws. Furthermore, Legal responsibility of Appraiser's mistakes in appraising will be an administrative and civil sanctions. To provide legal certainty and legal protection for the Appraisal profession requires a strengthening of regulations by the issuance of Law on Public Appraisers such as other supporting professions, namely Public Notary, Legal Consultant, and Public Accountant.
\end{abstract}

DOI: 10.18196/jmh.20190129

Copyright @ 2019 MEDIA HUKUM. All rights reserved.

\section{Introduction}

As an intermediary institution, a Bank's primary function is to raise funds and channel them in the form of credit or financing in accordance with Sharia principles to the society. In terms of giving Credit or financing Bank is often deal with the risks. Credit risk is a level of risk that is faced as a result of a period of time that separates between awarding credit and default to be accepted in the future. The longer the term credit is given, the higher level of risk for bank. 1Thus, in the implementation, both Conventional and Sharia Banks must comply with the prudential banking principle

${ }^{1}$ Mulyati, E. ( 2018). “The Implementation of Prudentian Banking Principles to Prevent Debtor with Bad Fait". Padjadjaran Journal of Law, 5(1): 89-107. 
and risk management. The bank's prudential principle is a logical consequence of the bank's function as an agent of trust ${ }^{2}$ that is obliged to maintain the public trust as the fund owners (depositor). Furthermore, this prudential banking principle must be interpreted in a broad sense, namely the bank's compliance with all legal provisions, including the Standard Operating Procedures made by the Bank in carrying out its activities. In practice, there are violations of the prudential principle. The violations are mostly on the absence of steps or procedures for granting credit as outlined in the Standard Operating Procedures. Meanwhile, the Standard Operating Procedures is mandated by Law No. 10 of 1998 on the Amendment to Law No. 7 of 1992 on Banking (Banking Law). Hence, the violations of Standard Operating Procedures are a form of a breach of the principle of prudence.

This opinion refers to on Article 8 Paragraph (2) and Article 15 of the Banking Law. Article 8 Paragraph (2) requires Commercial Banks to have and implement guidelines for credit and financing based on sharia principles, in accordance with the provisions stipulated by Bank Indonesia (now the Financial Services Authority). According to Article 15, it regulates the same obligations for Bank Perkreditan Rakyat (BPR) or Rural Bank. ${ }^{3}$ One form of violation of the prudential principle includes not registering Mortgage Right as an object of collateral so that the Bank does not have the right to execute collateral objects since the right to perform arises when the Mortgage Right is registered in the National Land Agency. ${ }^{4}$ In its development, the banking obligation to develop credit or financing guidelines is outlined in the Regulation of the Financial Services Authority No. 42/POJK.03/2017 on the Obligation to Compile and Implement Credit or Financing Policies for Commercial Banks.

Related to the provision of credit/financing, the implementation of the prudential banking principle is translated into the obligation of the Bank to analyze prior to granting a credit/financing. Thus, the bank obtains confidence in the ability of the Debtor to repay the debt or perform their obligations. The analysis includes Character; Capacity; Capital; Collateral, and Condition of economic (the $5 \mathrm{C}^{\prime} \mathrm{s}$ analysis of credit). Similar provisions regulated in Article 23 of Law No. 21 of 2008 on Sharia Banking which requires Sharia Banks or Sharia Business Units to carry out careful appraisals. Hence, banks have confidence in the willingness and ability of the customers (debtors).

Credit appraisal remains at the heart of the decision-making process leading to the granting of credit to a borrower. The banks experience problems with non-performing loans (NPLs) due to weak credit analysis. So, the purpose of credit appraisal is to help the bank make good credit decisions and help the bank avoid making incorrect decisions. The objective of credit appraisal is to determine the ability and willingness of the borrower to repay a requested loan in accordance with the terms of a loan contract. ${ }^{5}$

\footnotetext{
2 Otoritas Jasa Keuangan. (2016). Perbankan Seri Literasi Keuangan Perguruan Tinggi. Jakarta: Otoritas Jasa Keuangan, p. 6.

${ }^{3}$ Abubakar, L. \& Handayani, T. (2017). “Telaah terhadap Yuridis Implementasi Prinsip Kehati-hatian Bank dalam Aktivitas Perbankan Indonesia". Jurnal De Lega Lata, 2 (1): 68-91. doi: https://doi.org/10.30596/dll.v2i1.1157

4 Musjtari, D. N. (2013). "Penyelesaian Sengketa Perbankan Syariah dalam Perpspektif Hukum Progresif". Media Hukum, 20 (2): 302-316. http://journal.umy.ac.id/index.php/jmh/article/download/270/233

${ }^{5}$ Makomeke, P.C. et al. (2016). “The Effectiveness of Commercial Banks' Credit Appraisal Techniques in Improving Asset Quality". IOSR Jurnal of Economic and Finance, 7(5): 63-78.
} 
Collateral appraisal is a part of a loan appraisal and a loan appraisal system among financial institution can enhanced financial performance. ${ }^{6}$ In practice, a collateral appraisal is carried out by the bank's internal appraisers. The banks are not open to external appraisers to obtain objective assessments. At the end, the results of the assesment of the external Appraiser are reviewed by the bank's internal assessors. The assessment results will be taken into consideration for the bank to decide whether it is reasonable to grant a credit/financing or not, including the amount of credit/financing that can be given. The practices conducted at Bank Mandiri, for example, includes a calculation of collateral adequacy values based on fair market value from an Internal Appraiser, or from an Independent Appraiser after being reviewed by an Internal Appraiser.7 The urgency of collateral appraisal is in line with the function of collateral, primarily material collateral, by providing legal certainty for creditors that the debtor will carry out the obligation or repay their debts. If the debtor breaks the agreement (default) and the collateral is seized, the Bank expects the value of the collateral to cover all the debts or liabilities. In this case, the collateral is the second way out, if the first way out is the belief that the debtor is able to pay is unrealized. ${ }^{8}$ On the other hand, the debtor certainly expects that the sale of the assets will be in accordance with fair market prices and can pay off all of the debts/obligations, even more.

In performing collateral appraisals, the Bank can use both internal and external Appraisers. In accordance with Article 1 Number 2 and 3 of the Regulation of the Minister of Finance No. 56/PMK.01/2017 on Amendments to the Regulation of the Minister of Finance No. 101/PMK.01/2014 on Public Appraisers, Appraisers are "someone who has competence in conducting appraisal activities, who has at least passed the initial assessment Education." Meanwhile, Public Appraisers are "Appraisers who have obtained a permit from the Minister to provide services as stipulated in the Regulation of the Minister of Finance on Public Appraisers." Appraisal procedures and mechanisms carried out by the Public Appraiser based on Article 4 of the Regulation of the Minister of Finance of the Republic of Indonesia Number 101/PMK.01/2014 are as follows: 1. identify and understand the scope of the assignment; 2. collecting, selecting and analyzing data; 3 . applying the valuation approach; and 4 . prepare a valuation report. The application of the valuation approach as referred in Article 4 use the method: a) market data approach or often also called (sales comparation method) or direct market comparison method is a valuation method that is carried out by directly comparing the property valued with similar property data; b) cost approach, using the Cost Calculation Method, Property values (Land and Buildings) are obtained by considering land as vacant land, land value is calculated using the market data approach method. While the building value is calculated using the cost calculation method; and c) income approach, where the value of the property depends on the ability of the property to generate profits. ${ }^{9}$

\footnotetext{
${ }^{6}$ Katula, R. (2018). “Loan Appraisal and Financial Performance of Deposit Taking Savings and Credit Cooperative Societies in EMBU County, KENYA". International Journal of Research in Finance and Marketing (IJRFM), 8(5): 1-8.

7 Nuraini, V. (2019). Penilaian Agunan di Bank Mandiri. Bandung: Bank Mandiri, p. 5.

8 Rahman, Y. (2015). “Malpraktik Jasa Penilai pada Bank tentang Hasil Laporan yang Nilainya Melebihi Harga Pasar". Jurnal Hukum Bisnis, 1 (1): 39-51. doi: https://doi.org/10.33121/hukumbisnis.v1i1.56.

9 Setianingrum, R.B. (2016). “Mekanisme Penentuan Nilai Ekonomis dan Pengikatan Hak Cipta sebagai Objek Jaminan Fidusia”. Media Hukum, 23(2): 229-238, DOI: 10.18196/jmh.2016.0083.229-238.
} 
In addition to the purpose of securing credit, a collateral appraisal is carried out for the purpose of execution of collateral. With regards to loan collateral auction, Article 43 of the Regulation of the Minister of Finance No. 27/PMK.06/2016 on Auction Implementation Guidelines stipulates, "every auction is required to have a Limit Value, and the determination of the limit value is the responsibility of the seller." Furthermore, Article 44 stipulates that the seller determines the Limit Value based on the appraisal by the Appraiser; or valuation by valuator, and Article 45 (b) specifies that the Limit Value must refer to the assessment of the Appraiser in terms of "execution of auction of Article 6 of the Law on Mortgages, Fiduciary execution auction and bankruptcy execution action with a minimum Limit Value of IDR 1,000,000,000.00 (one billion Rupiah).

The appraisal profession shows a rapid development year by year. It is because the growth of business and economic activities needs to be managed transparently and accountably in order to create a healthy and efficient economy. An independent, professional and competent appraisal of assets will encourage the public, business actors and the government to make the right decisions based on professional considerations. Therefore, the results of assessment conducted by an Appraiser will make a significant contribution to support the decision-making process. The development of business drives the growth of Appraiser services, especially Public Appraisers, both as individuals and as an institution, i.e., Public Appraisal Service Office or the Branches Office. Based on the data from the Ministry of Finance of the Republic of Indonesia, the development of the profession of public appraisers can be seen in the following table:

Table 1. Development of Public Appraisers, Office of Public Appraisal Service and the Office Branches in Indonesia

\begin{tabular}{ccccc}
\hline No. & Year & Public Appraisers & $\begin{array}{c}\text { Office of Public } \\
\text { Appraisal Service }\end{array}$ & $\begin{array}{c}\text { Office of Public } \\
\text { Appraisal Service } \\
\text { Branch }\end{array}$ \\
\hline 1 & 2015 & 444 & 117 & 111 \\
2 & 2016 & 569 & 118 & 235 \\
3 & 2017 & 630 & 120 & 292 \\
4 & 2018 & 687 & 123 & 341 \\
\hline
\end{tabular}

Source: Ministry of Finance, 2019.

In addition to the growth in the number and distribution of appraiser profession in all provinces in Indonesia, the growth of appraisal assignments and income of the Office of Public Appraisal Service is increasing parallel with the development of the profession of Public Appraisers. In addition to banking as a significant user of the services of a professional appraiser-or assignor-business activities that use appraisers' services cover various fields. The following are data of assignors based on the number of assignments in 2017 as an illustration of the use of Appraisal services. 
Table 2. Assignors and Number of Assignments

\begin{tabular}{|c|c|c|}
\hline No. & Assignors & $\begin{array}{l}\text { Number of } \\
\text { Assignments }\end{array}$ \\
\hline 1 & Banking & 158.855 \\
\hline 2 & Trading & 4.401 \\
\hline 3 & Financing services & 2.538 \\
\hline 4 & Manufacture & 2.416 \\
\hline 5 & Government & 2.319 \\
\hline 6 & Construction & 1.201 \\
\hline 7 & Company & 1.180 \\
\hline 8 & Agriculture, Plantation, Forestry and livestock & 1.061 \\
\hline 9 & Individual & 1.006 \\
\hline 10 & Transportation & 820 \\
\hline
\end{tabular}

Source: Ministry of Finance, 2019.

From the number of appraisal assignments of 29,999 in 2010 and increased to reach 189,969 in 2017. Meanwhile, ssion choice besides other professional services such as Legal Consultant, Public Accountant or Notary.

On the other hand, along with the rapithere is also a rise in income of the Office of Public Appraisal Service from IDR 181 billion to IDR 1,096 billion. As a result, the Appraisal profession is an attractive profed growth of the Appraisal profession, legal problems began to arise related to Appraisal services. In the practice of assessing bank credit collateral, the appraiser becomes a profession that is vulnerable to lawsuits due to the potential losses suffered either by the bank or the debtor. Possible claims can arise from the appraisal results that are too high at the time of the collateral appraisal but low at the time of execution, or an error occurs due to a superficial investigation resulting in a mistake in valuing the collateral. In practice, the appraisal results that are often disputed are the valuation reports whose purpose is used for asset auction when the asset becomes loan collateral. Banks, as collateral holders, that will execute collateral through the auction office use Appraisers' service to assess the price of the collateral. A determination of a limit price that is considered too low is deemed detrimental to the asset owner and, often, becomes the basis of a lawsuit in claiming compensation. It can be seen in Bangil District Court Decision No. 36/pdt.G/2012/PN Bangil dated 22 July 2013 and pronounced in an open session on 31 July 2013 or Decision of the Supreme Court No. 471K/Pdt/2015 dated 28 August 2015. In addition to civil losses, in some instances, the appraisal profession has the potential to face criminal charges in conducting their profession. The indictment of the public prosecutor for 6 years in prison against the Office of Public Appraisal Service leaders, Syamsul Hadi, in 2013 Medan Corruption Crime hearing was considered strange by the Head of Indonesian Society of Appraisers because, all this time, Appraisers were only called to act as a witness in determining assets, not as a defendant. The Prosecutor should first ask for an opinion from the Appraisal Board, that is authorized to examine Appraisers who are suspected of violating the Indonesian Valuation Standards and the Code of Ethics. Moreover, the prosecutor mentioned a violation of the appraisal standards. Thus the charge of corruption is inappropriate. ${ }^{10} \mathrm{With}$ regard to this case,

10 Medan Bisnis Daily. (2013). Ketum MAPPI: Aneh dan Pertama di Indonesia. Available online from: http://www.medanbisnisdaily.com/news/read/?id=36683. [Accessed June 25, 2019]. 
the Head of the Board believes that only Indonesian Society of Appraisers has the authority to declare whether or not an Appraiser has violated the Indonesian Valuation Standards. ${ }^{11}$

In addition to the aforementioned legal issues, unlike other professions, the Appraiser profession that is under the Indonesian Society of Appraisers has not explicitly been regulated by the law. Hence, it is difficult for the Indonesian Society of Appraisers and the Appraisal profession to obtain assurance and legal protection in carrying out their job. Therefore, the Indonesian Society of Appraisers hopes for a solid legal foundation like other professions. Based on the statement of the background, the problems can be identified as follows: 1) What is the legal relationship between the Bank and the Appraiser to appraise the collateral for bank credit?; 2) What is the Appraiser's responsibility to the credit collateral appraisal result?; And 3) Do the Appraisal professional regulations have provided optimal legal protection for the Appraisal profession in Indonesia?

\section{Method}

This research is a normative juridical research which focuses on examining the application of the rules or norms in positive law. ${ }^{12}$ This article also used the positivist legis conception approach. This concept views the law as identical with written norms created and promulgated by authorized institutions. This conception views the law as a normative and independent system. ${ }^{13}$ The research is descriptive-analytical since it make a systematic, factual, and accurate description of the facts. Therefore, the study examines and describes legal aspects of issues relating to the position and responsibility of Appraisers in appraising collateral for bank credit/financing. The method applied in this study is normative juridical approach by prioritizing an analysis of secondary data in the form of primary legal materials, the legislation; secondary legal documents, both journals and the results of previous studies; and tertiary legal materials. In addition, the data are analyzed qualitatively and juridically.

\section{Analysis and Results}

\subsection{Legal Relations between Banks and Public Appraisers}

Banks as an intermediary institution are required prudential principles to be applied, particularly in channeling funds through credit or financing to ensure that the debtor or customer has the intention and ability to pay. ${ }^{14}$ Regarding the prudential banking principles, there is one profession that supported the banks namely, public appraisers. Public Appraisers are one of the supporting professions that have an essential role in business activities and the financial services sector, especially banking, capital markets, and financial institutions. Performance appraisal is no doubt, a management tool for

\footnotetext{
11 Medan Bisnis Daily. (2013). Hanya MAPPI Berwenang Nyatakan Pelanggaran SPI. Available online from: http://www.medanbisnisdaily.com/news/read/2013/03/02/15813/hanya-mappi-berwenangnyatakan-pelanggaran-spi/. [Accessed June 25, 2019].

12 Ibrahim, J. (2006), Teori dan Metodologi Penelitian Hukum Normatif. Malang: Bayumedia Publishing, p. 295.

13 Soemitro, R.H. (1988), Metodologi Penelitian Hukum dan Jurimetri. Jakarta: Ghalia Indonesia, p. 13-14

14 Abubakar, L. (2018). “Implementasi Prinsip Kehati-hatian Melalui Kewajiban Penyusunan dan Pelaksanaan Kebijakan Perkreditan atau Pembiayaan Bank". Jurnal Rechtidee, 13(1): 62-81.
} 
aligning corporate performance with individual performance. It is used for many different purposes such as pay increases, improvement and training, transfers, compensations, promotion, employee recognition, and termination. ${ }^{15}$

From the banking sector, the objectives of appraisal are for loan collateral appraisal that refers to Indonesian Valuation Standards 202 and the assessment for Auction Objectives related to the Indonesian Valuation Standards 205 of 2018. The evaluation for Loan Collateral at the initial stage aims to provide comfort to the authorities in considering credit, monitoring facilitation, risk mitigation, and calculation of the Impairment Loss/Decrease Adequacy Reserves, namely provisioning of losses on credit and funding portfolios that have decreased economic value. ${ }^{16}$ It relates to the responsibilities of the credit approval officer or financing officer regulated in the Regulation of the Indonesian Finance Service Authority on the Obligation to Compile and Implement Credit or Financing Policies for Commercial Banks that at least includes:

a. ensuring that every credit or financing granted has met banking requirements and following sound credit or financing principles;

b. ensuring that the implementation of credit or financing granting is under the Bank's Policy on Credit and Financing as well as the Implementation Guidelines for Credit or Financing;

c. ensuring that the granting of credit or financing lays on an honest, objective, careful and thorough appraisal and free from the influence of the interested parties in the credit or financing applicant; and

d. believing that the granted credit or financing can be repaid in time and will not turn into a problematic credit or financing.

As a profession that provides appraisal services, a legal relationship between a Public Appraiser and the assignor (bank) is a contractual relationship as outlined in the agreement. In practice, the agreement is made between the Central Office of Public Appraisal Service and the Bank (Central Bank Office). This legal relationship results in an event when one party does not fulfill its obligations (default); the law shall enforce that the commitment will be fulfilled. ${ }^{17}$

Beside arising from the agreement, the legal relationship between the Appraiser and the bank also comes from the legislation. The definition of legislation here includes the Indonesian Valuation Standards and the Indonesian Appraisal Code of Ethics derived from the Regulation of the Minister of Finance on Public Appraisers. With regards to the appraisal for Loan Collateral (bank credit/financing), Appraisers must understand banking regulations that prioritize the prudential banking principle and risk management. It is closely related to the position of Public Appraisers as Affiliated Parties. Based on Article 1 Number 22 (c) of the Banking Law, "Affiliated Parties are

\footnotetext{
15 Dey, S (2015), Performance Appraisal of Commercial Bank's Executives: A Study of Selected Private Commercial Banks In Bangladesh, $4^{\text {th }}$ International Conference on Managing Human Resources at The Workplace.

${ }^{16}$ Apriyantho, K. V. (2016). Analisis Penerapan Cadangan Kerugian Penurunan Nilai (PSAK 55). Indonesian Bankers Club. Available online from: https://indonesianbankersclub.wordpress.com/2016/09/22/analisis-penerapan-cadangan-kerugianpenurunan-nilai-psak-55/. [Accessed June 25, 2019].

17 Badrulzaman, M. D. (2015). Hukum Perikatan dalam KUHPerdata-Yurisprudensi, Doktrin serta Penjelasan. Bandung: Citra Aditya Bakti, p. 16.
} 
parties that provide services to banks, including public accountants appraiser, legal consultant, and other consultants." The juridical consequences of the position of the Public Appraiser as an affiliated Party stipulated in several articles in the Banking Law applies to Appraisers, namely:

a. Article 47 Paragraph (2): "Members of the Board of Commissioners, Board of Directors, bank employees or other Affiliated Parties who intentionally disclose information that must be kept confidential under Article 40 shall be punished with imprisonment of a minimum of 2 years and a maximum of 4 years and a fine of at least IDR 4,000,000,000.00 (four billion) and a maximum of IDR 8,000,000,000.00 (eight billion). Article 40 stipulates that what must be kept confidential is the data on depositor and the deposit.

b. Article 50: "Affiliated Parties that intentionally do not implement the steps needed to ensure bank compliance with the provisions in the Banking Law and other laws and regulations that apply to banks, shall be punished with imprisonment of at least 3 years and a maximum of 8 years and a fine of at least IDR 5,000,000,000.00 (five billion) and a maximum of IDR 100,000,000.00 (one hundred billion).

Referring to Article 50, Appraisers have the potential to commit a criminal offense in carrying out their profession if they do not carry out the necessary steps. Errors in Assessments that can result in a bank making a wrong business decision can result in a violation of Article 50, which is classified as a criminal offense. However, this Article requires an element of intention. Hence, errors resulting from negligence or accidental actions do not incorporate violations of Article 50.

In addition to the Banking Law, the legislation that governs the appraisal profession is the Regulation of the Minister of Finance on Public Appraisers. To provide legal protection and legal certainty for service users and Appraisers, the Government, in this case, the Ministry of Finance, requires the Public Appraisal profession to obtain a permit to support the financial services sector. Besides, Regulation of the Minister of Finance on Public Appraisers regulates the conditions that must be met to obtain a license as a Public Appraiser granted by the Minister and stipulated in a Ministerial Decree. Public Appraisal Permit is classified in the following service sector: 1) Simple property appraisal; 2) Property appraisal; and 3) Business appraisal. In addition to administrative obligations, Article 4 Paragraph (2) of the Regulation of the Minister of Finance on Public Appraisers stipulates that the appraisal process must be carried out by the Indonesian Valuation Standards as the guideline in conducting assessments.

Currently, the valid Indonesian Valuation Standard is the VII-2018 Edition compiled by the Indonesian Valuation Standards Committee and the Indonesian Society of Appraisers. The Indonesian Valuation Standards compilation refers to the International Valuation Standards (IVS) 2017 issued by the International Valuation Standards Council. The International Valuation Standards serve as the main guidelines for appraisal professionals around the world and will support the consistency, transparency, and trust in the appraisal that are key to investment, reporting, financial and financial market stability decisions. Also, IVS is the recent step in IVSC's mission 
to raise the standards of international valuation practices as a core part of the financial system for the benefit of the capital market and the public interest. ${ }^{18}$

The Indonesian Valuation Standards compilation aims to: 1) encourage the Appraiser to carefully determine and understand the needs and requirements from the Assignor, and to provide certainty to the Appraiser that the Appraiser is provided with an adequate standard of assessment to meet the needs; 2) promote the use of basic appraisal and assumption consistently in the evaluation and selection of a proper appraisal basis according to the needs of the Assignor; 3) assist Appraisers in achieving professional competence with standards that are in line with the international guidelines in preparing and implementing appraisal works; and 4) ensure that the assessment report is comprehensive and not misleading, contains understandable information that needs to be obtained by the reader; and ensure that references published in the appraisal report including clear, accurate and adequate information.

Furthermore, Appraisers must comply with the Indonesian Appraisal Code of Ethics. Naturally, the primary function of the Appraiser profession is as a carrier the trust of the community (fiduciary duty). Therefore, the essence of the Appraisal profession is the recognition of the community that the Appraiser has specialized expertise and integrity, honesty and objectivity in carrying out the job. Therefore, Indonesian Appraisal Code of Ethics is a moral foundation for Appraisers in carrying out their duties. There are 5 (five) basic ethical principles as fundamental values or moral norms that regulate the behavior of Professional Appraisers that are binding, namely: 1) integrity: having the honesty and trustworthiness in professional and business relationships, and upholding the truth and fairness; 2) objectivity: avoiding conflicts of interest, or are not influenced or impartial in professional or business considerations; 3 ) competence: maintaining the professional knowledge and skills needed to ensure that the appraisal results have been made based on the latest developments in appraisal practices and techniques as well as legislation; 4) confidentiality: maintaining the confidentiality of information obtained in professional and business relationships, and not disclose such information to third parties without permission, or to be used as information for personal benefit of the Appraiser or third parties; 5) Professional Behaviour: carrying out work in accordance with the scope of the assignments agreed upon in the contract, and refer to Indonesian Valuation Standards. Always act in the public interest and avoid actions that discredit the Appraiser profession. ${ }^{19}$ In appraisal practices, the Indonesian Valuation Standards and Indonesian Appraisal Code of Ethics are an integral unit. Hence, it can be concluded that the legal relationship between Appraisers and Banks in conducting appraisal for loan collateral can be from the legislation, including Banking Law, Regulation of the Minister of Finance on Public Appraisers, Indonesian Valuation Standards 2018 and Indonesian Appraisal Code of Ethics as well as other related regulations; and Contract between Appraiser and Bank.

\footnotetext{
18 The International Valuation Standards Council. (2019). IVS-A Benchmark for Global Valuation Practice. Available online from: https://www.ivsc.org/news/article/ivsc-launches-new-global-standards-forvaluation-profession. [Accessed June 25, 2019].

19 KPSPI \& MAPPI. (2018). KEPI \& SPI - Kode Etik Penilai Indonesia dan Standar Penilaian Indonesia - Edisi VII2018. Jakarta: KPSPI \& MAPPI, p. 3.
} 
3.2. The Obligations and Responsibilities of Appraisers in Appraising for the Purpose of Loan Collateral (Collateral Appraisal for Bank Credit/ Financing)

The primary source of obligations of the Appraiser comes from a Collateral Assessment Cooperation Contract between the Appraiser and the Bank. It is per the requirements stipulated in the scope of assignment (Indonesian Valuation Standards 103) that "in so far as the applicable laws and regulations do not regulate it, the appraisal for loan collateral must refer to the scope of the assignment agreed between the Assignor and the Appraiser." This agreement is stated in a Collateral Assessment Cooperation Contract between the Bank as the Assignor and the Appraiser as the Assignee. In practice, it was found that for a straightforward property appraisal for loan collateral, the assignment designation relied solely on a Work Implementation Letter. Therefore, the Appraiser must ensure that the Work Implementation Letter has been bound to the master Collateral Assessment Cooperation Contract agreed upon by the assignor and/or the user of the report with the Appraiser. ${ }^{20}$ All agreements must reflect on the requirements regulated by Indonesian Valuation Standards 103.

As an agreement that is developing in business practice, a contract between an Appraiser and a Bank is required to fulfill the legal requirements of a commitment and general principles in the agreement stipulated in Book III of the Civil Code. For instance, a Collateral Assessment Cooperation Contract between Bank BCA and Office of Public Appraisal Service. The substance of the agreement includes, among others: Definition; Appointment of Appraisers to Conduct Collateral Appraisal; Appraisal by the Bank, Provisions for Collateral Appraisal, Process of Appraisal and Report on Appraisal Results; Sanctions for Late Collateral Appraisal Results submission and/or Errors in Appraisal Results; Obligation of the Appraiser to Maintain Confidentiality; Term and Termination of the Agreement; Amendment to the Agreement (Addendum); Force Majeure; Prohibition of Transfer of Obligations; Correspondence and Dispute Settlement. In addition to having to be in writing, viewed from the substance and format of the contract, the agreement is a standard contract whose clause is determined by the Bank. By referring to the cooperation agreement, the Appraiser's principal obligation is to conduct an independent, professional and competent appraisal in accordance with the profession. What is meant by appraisal is "a work process to provide written opinions on the economic value of an object of valuation under the Indonesian Valuation Standards and Indonesian Appraisal Code of Ethics." Furthermore, the Appraiser submits an Appraisal Report, namely a written document that contains an opinion on the economic value of an object of Assessment signed by the Public Appraiser. Credit appraisal is mainly carried out to determine whether to accept or reject the proposal for credit. It involves evaluating the loan application to find out the borrower's repayment capacity. The primary objective is to ensure the safety of the money of the bank and its customers. The appraisal process involves an evaluation of credit worthiness of the borrower and future expected stream of cash flows with the amount of risk attached to a specific borrower. ${ }^{21}$

If Appraisers do not carry out their duties by the contract agreement, in the sense that they fail to conductor submit a late or erroneous appraisal, then the Appraiser is civilly responsible for compensation. In practice, the responsibility to compensate for this is included in the contract agreement on "fine sanction," not "compensation." Furthermore, the mechanism of this fine is carried out by determining a certain percentage calculated from the amount of collateral appraisal service fees for the

\footnotetext{
20 Yusuf, H. (2019). Standar Penilaian Indonesia 202 (SPI 202) Penilaian untuk Tujuan Penjaminan Utang - SPI Edisi 2018. Jakarta: SPI, p. 6.

${ }^{21}$ Njeru, et.al. (2016). “Effectiveness of Credit Appraisal on Loan Performance of Commercial Banks in Kenya". International Journal of Recent Engineering Research and Development (IJRED), 1(6): 9-14.
} 
Collateral Result Report, both due to delays and errors. In addition to losses arising from contract agreements, it can also arise from non-compliance with laws and regulations. In some cases, the debtor who owns the collateral good suffers loses when the collateral is executed or auctioned, not at the time of the collateral appraisal for loan. In practice, a loss, for example, arises from the determination of a price limit that is too low, or from the results of an appraisal that does not follow the appraisal standards as stipulated in the Indonesian Valuation Standards that is supposed to be heeded by all Appraiser. Thus, the potential for civil losses can arise from violations of legal provisions or acts against the law as stipulated in Article 1365 of the Civil Code. It means that the party who suffers losses due to a violation of regulation by the appraiser must prove that the Appraiser made a mistake, not only has violated the laws and regulations but also contradicts the personal obligations of the Appraiser as a profession that support the financial service sector or moral responsibility. Especially for Appraisers, this moral obligation is translated into Appraiser's ethics contained in the Indonesian Appraisal Code of Ethics. Thus, it can be concluded that the Appraiser's responsibility in appraising collateral for bank credit/financing may arise due to administrative, civil and criminal violations.

\subsection{The Urgency of Strengthening Regulations as a Means of Legal Protection for Appraisal Professionals}

Comparing to other professions that support the financial service sector, an appraisal profession is the only profession that does not yet have a solid legal foundation in the form of legislation. The regulations governing the Appraisal profession are currently in the form of administrative Ministerial Regulations or some form of provisions for the appraisal profession in the Capital Market. In addition to those regulations, the legal relationship between the assignor and the Appraiser refers to the contract agreed upon by the parties. It is different from other professions that have been regulated in a special law that governs such professions. To take a case in point, the notary profession is regulated in Law No. 2 of 2014 on Amendments to Law No. 30 of 2004 on Notary; the advocate profession is regulated in Law No. 8 of 2003 on Advocates, and accountant profession is regulated in Law No. 5 of 2011 on Public Accountants. The existence of the law on Appraiser profession is urgent because the Appraiser profession is increasingly needed to encourage accelerated sustainable economic development that requires a healthy and efficient national economy and meets transparent and accountable management principles. Appraisal results are part of professional considerations that make essential contributions to support the economic decision-making process. On the other hand, the development of Appraisal profession requires certainty and guarantee of legal protection for this profession so that it can conduct its job well. Currently, legal protection for the Appraisal profession is facilitated by a professional organization: the Indonesian Society of Appraisers. Aside from being a forum for the Appraisal profession and its service business entities in achieving common goals, it acts as an organization that protects its members as executors of the Appraisal profession and unprofessional actions. Besides, for the benefit of its members, the Indonesian Society of Appraisers functions as follows:

a. upholding the Professional Appraisers norms of nobility, authority and trustworthy; 
b. initiating relationships with other parties for the interests of the Appraiser Profession;

c. as a referral organization for the member in carrying out appraisal practice activities;

d. as an organization that develops and fosters Appraisal Professionals and Appraisal service business entities;

e. as an organization that compiles, establishes, and oversees the implementation of the Indonesian Appraisal Code of Ethics and Indonesian Valuation Standards.

Referring to the above functions, the legal protection that can be provided by the Indonesian Society of Appraisers as an organization is only related to appraisal practices in so far as it does not violate the Indonesian Appraisal Code of Ethics and Indonesian Valuation Standards. Besides, the Organization also gives administrative sanctions for the members and business entities for violations of Indonesian Appraisal Code of Ethics and Indonesian Valuation Standards. This function is carried out by the Appraisal Board, an organizational body that oversees professional compliance and the appraisal practice in relation to Indonesian Appraisal Code of Ethics and Indonesian Valuation Standards. As for implementing the arbitration function, the Appraisal Board can refer to the applicable legislation.

Performance appraisal is a significant element of the information and control system of the organisation such as Banks. The application of performance appraisal are given below: 22

a. Performance appraisal provides valuable informastion for personnel decisions.

b. Help to judge the effectiveness of recruitment, selection, placement, and orientation systemsof the organisations

c. It is useful in analysing training and development needs. Theese needs can be assessed because performance appraisal reveals people who require further training to remove their weaknesses.

d. Performance appraisal can be used to improve performance through appropriate fedback to employees.

In practice, Appraisers who are involved in both civil and criminal cases have not explicitly participated the Indonesian Society of Appraisers as a professional organization to provide expert opinion to position the case accurately. Some instances that occurred include wrong location (identified during an auction process); an object appraisal that is inconsistent when another evaluation is conducted (between house or shop); and the lawsuit of a debtor on overvalued/undervalued due to different levels of investment depth when granting debt and auction requirements. ${ }^{23}$

Another example that has the potential to be disputed is the use of assumptions in the appraisal process in addition to stating the value of an asset. Assumptions are a natural thing to accept as facts in the context of appraisal assignments without specific investigation or verification. 2 types of hypotheses can be used by Appraisers to obtain

\footnotetext{
22 Moyal, S et.al (2016)."Performance Appraisal in Banks : A study". ELK Asia PAsific Journal of Human Resource Management and Organisational Behaviour, 3(1): 1-8.

${ }^{23}$ Nuraini, V. Op.Cit., p.10.
} 
in-depth investigation, namely: specific assumptions and general assumptions. If the Appraiser faces limitations in conducting a thorough investigation, specific assumptions will be used, but if the restrictions are not significant towards appraising the value, then a general assumption is used. This assumption must be recorded in the Appraisal Report. With regards to specific assumptions, there are two types of assumption, namely:24

a. Extraordinary assumptions; assumptions where there are essential matters to be identified, but it not fulfilled, such as the Appraiser cannot identify the property in full but can only see the outside of the building.

b. Hypothetical Conditions assumption when there is a difference between the current condition and something planned such as the Appraiser is assigned to make an appraisal on a state of a property (land). Meanwhile, the property is not there yet, but it is assumed the building has been completed on the appraisal date.

Specific assumptions and general assumptions are general concepts and principles of appraisal as part of the Indonesian Valuation Standards. Therefore, particular assumptions and general assumptions can be used in the assessment process as long as it is reasonable and relevant without ignoring the purpose of the assessment. ${ }^{25}$ The use of premises must meet the requirements, namely: an assessment is considered correct, accepted in appraisal understanding, must be reasonable, and verification is impossible. If observed, these cases arise as a result of violations of the Indonesian Valuation Standards, so that the settlement is carried out using an administrative or civil, not criminal approach. Therefore, in cases involving an Appraiser profession as a party, accurate considerations are needed to decide a case. Therefore, Indonesian Society of Appraisers, as a professional organization should be used as a reference to obtain comprehensive knowledge before the judge decides a case, both civil and criminal.

In addition to legal protection through Indonesian Society of Appraisersas a professional appraisal organization, the law reinforcement is needed to regulate a comprehensive and integrated Appraisal profession as a legal umbrella for the Appraiser profession. Referring to the regulation of other professions that support financial services sectors that are regulated in the form of laws, it seems that the idea of establishing a law on Public Appraisers is a concrete step to encourage the growth of independent, professional, and competent Appraisers profession. With the issuance of Law on Public Appraisal, the existence of the Indonesian Society of Appraisers, the Indonesian Valuation Standards, and Indonesian Appraisal Code of Ethics may have a firm legal umbrella and a legal basis.

\section{Conclusion}

The legal relationship between the Bank and the Appraiser to appraise the collateral for bank credit is arising from the agreement, and also comes from the legislation. It can be concluded that the position of an Appraiser in appraisal for loan collateral for the provision of credit or bank financing is as a supporting profession for the financial services sector. The Appraiser's responsibility to the credit collateral is included as

\footnotetext{
24 Yusuf, H. Op.Cit. p. 41.

${ }^{25}$ KPSPI \& MAPPI. Op.Cit., p. 13.
} 
affiliated Parties that are obliged to carry out their job carefully in order to ensure that the Bank complies with all banking regulations and other related regulations. Therefore, the potential loss due to the failure to carry out the Appraisers' obligations, both arising from the agreement and the legislation, will result in civil liability in the form of compensation. The Appraisal professional regulations have not provided optimal legal protection yet for the Appraisal profession in Indonesia. Given the development of the Appraisal profession, to encourage healthy and sustainable economic growth, it is necessary to strengthen the regulation of the Appraiser profession, such as other professions that have been regulated in the law and legislation. Therefore, strengthening of regulation of the appraisal profession is urgent to provide legal certainty and protection as well as to become a solid legal basis for the existence of the Appraisal profession as a helping profession for the financial services sector.

\section{References}

\section{Books:}

Badrulzaman, M. D. (2015). Hukum Perikatan dalam KUHPerdata-Yurisprudensi, Doktrin serta Penjelasan. Bandung: Citra Aditya Bakti.

Ibrahim, J. (2006). Teori dan Metodologi Penelitian Hukum Normatif. Malang: Bayumedia Publishing.

KPSPI \& MAPPI. (2018). KEPI E SPI - Kode Etik Penilai Indonesia dan Standar Penilaian Indonesia - Edisi VII-2018. Jakarta: KPSPI \& MAPPI.

Nuraini, V. (2019). Penilaian Agunan di Bank Mandiri. Bandung: Bank Mandiri.

Soemitro, R.H. (1988). Metodologi Penelitian Hukum dan Jurimetri. Jakarta: Ghalia Indonesia.

Tim Penyusun OJK. (2016). Perbankan- Seri Literasi Keuangan Perguruan Tinggi. Jakarta: Otoritas Jasa Keuangan.

Yusuf, H. (2019). Standar Penilaian Indonesia 202 (SPI 202) Penilaian untuk Tujuan Penjaminan Utang - SPI Edisi 2018. Jakarta: SPI.

\section{Journal Articles:}

Abubakar, L. (2018). "Implementasi Prinsip Kehati-hatian melalui Kewajiban Penyusunan dan Pelaksanaan Kebijakan Perkreditan atau Pembiayaan Bank". Jurnal Rechtidee, 13(1): 62-81.

Abubakar, L. \& Handayani, T. (2017). “Telaah terhadap Yuridis Implementasi Prinsip Kehati-hatian Bank dalam Aktivitas Perbankan Indonesia". Jurnal De Lega Lata, 2(1): 68-91. doi: https://doi.org/10.30596/dll.v2i1.1157.

Katula, R. (2018). "Loan Appraisal and Financial Performance of Deposit Taking Savings and Credit Cooperative Societies in EMBU County, KENYA" International Journal of Research in Finance and Marketing (IJRFM), 8(5): 1-8. 
Moyal, S \& Iyengar, V. (2016). "Performance Appraisal in Banks: A Study". ELK Asia Pasific Journal of Human Resource Management and Organisational Behaviour, 3(1):18.

Mulyati, E. ( 2018). “The Implementation of Prudentianl Banking Principles to Prevent Debtor with Bad Faith". Padjadjaran Journal of Law, 5(1): 89-107.

Musjtari, D. N. (2013). "Penyelesaian Sengketa Perbankan Syariah dalam Perpspektif Hukum Progresif". Media Hukum, 20(2): 302-316. http://journal.umy.ac.id/index.php/jmh/article/download/270/233.

Rahman, Y. (2015). “Malpraktik Jasa Penilai pada Bank tentang Hasil Laporan yang Nilainya Melebihi Harga Pasar". Jurnal Hukum Bisnis, 1(1): 39-51. doi: https://doi.org/10.33121/hukumbisnis.v1i1.56.

Setianingrum, R.B. (2016), "Mekanisme Penentuan Nilai Ekonomis dan Pengikatan Hak Cipta sebagai Objek Jaminan Fidusia", Media Hukum, 23(2): 229-238, doi: 10.18196/jmh.2016.0083.229-238.

\section{Internet:}

Apriyantho, K. V. (2016). Analisis Penerapan Cadangan Kerugian Penurunan Nilai (PSAK 55). Indonesian Bankers Club. Available online from: https://indonesianbankersclub.wordpress.com/2016/09/22/analisis-penerapancadangan-kerugian-penurunan-nilai-psak-55/. [Accessed June 25, 2019].

Dey, S. (2015), Performance Appraisal of Commercial Bank's Executives: A Study of Selected Private Commercial Banks In Bangladesh, $4^{\text {th }}$ International Conference on Managing Human Resources at The Workplace.

Medan Bisnis Daily. (2013). Hanya MAPPI Berwenang Nyatakan Pelanggaran SPI. Available online from:

http:// www.medanbisnisdaily.com/news/read/2013/03/02/15813/hanyamappi-berwenang-nyatakan-pelanggaran-spi/. [Accessed June 25, 2019].

Medan Bisnis Daily. (2013). Ketum MAPPI : Aneh dan Pertama Di Indonesia. Available online from: http:// www.medanbisnisdaily.com/news/read/?id=36683. [Accessed June 25, 2019].

The International Valuation Standards Council. (2019). IVS-A Benchmark for Global Valuation Practice. Available online from: https://www.ivsc.org/news/article/ivsc-launches-new-global-standards-forvaluation-profession. [Accessed June 25, 2019]. 